\title{
Distribution of Nutrients and Chlorophyll-a in a coastal waters and mesotidal estuary of Ilaje, Ondo state, South Western, Nigeria.
}

\author{
Opeyemi Otolorin Oyatola ${ }^{1}$,Samuel Olatunde Popoola ${ }^{1}$, Olubunmi Ayoola Nubi ${ }^{1 *}$, Falilu Olaiwola Adekunbi ${ }^{1}$, Ekundayo \\ Oluwaseu Adeyemi ${ }^{1}$ \\ ${ }^{1}$ Department of Physical and Chemical Oceanography, Nigerian Institute for Oceanography and Marine, PMB, 12729, Victoria Island, \\ Lagos. Nigeria \\ * Correspondence E-mail address: nubiao@niomr.gov.ng (O A, Nubi).
}

DOI: 10.29322/IJSRP.11.10.2021.p11840

http://dx.doi.org/10.29322/IJSRP.11.10.2021.p11840

\begin{abstract}
The nutrients (nitrate, nitrite, phosphate and silicate) of thirty-two study stations in the Ilaje, coastal waters and Estuaries of Ondo State, Nigeria were studied in the month of August (during the wet season). These 32 stations consist of two Estuaries Awoye (A1 A6), Abereke (AB1 - AB7), and anthropogenic impacted stations (I1 - I12) and control stations (C1 - C7). The aim of this study is to evaluate the eutrophication status of the Ilaje coastal waters and Estuaries in response to the stress caused by anthropogenic inputs from land use changes, agriculture, and industrial effluents. Our study showed highest nitrate $(3.20-6.98 \mathrm{mg} / \mathrm{L})$ and phosphate $(11.59$ - $17.48 \mathrm{mg} / \mathrm{L})$ concentrations at the Abereke Estuaries. The significant correlation of nitrate with chlorophyll-a $(\mathrm{p}<0.01, \mathrm{r}=+0.886)$ suggest that nitrate is the primary limiting nutrient for phytoplankton production, and accounted for the high chlorophyll-a concentrations in the study area (Table 2). The mean nitrate concentrations of $0.13 \mathrm{mg} / \mathrm{L}$ at the impacted stations above the maximum permissible limit of nitrate $(0.06 \mathrm{mg} / \mathrm{L})$ for Tilapia production suggest an unfavorable environment for the Tilapia fishes' growth at the impacted stations. The chlorophyll-a concentrations scale further showed that the study area is characterized as bad eutrophication status $(>2.21 \mu \mathrm{g} / \mathrm{L})$. This has further showed that more studies on eutrophication status in the Nigeria coastal waters need to be intensified based on the paucity of information on the baseline data.
\end{abstract}

Keyword: Nutrients, Ilaje, Coastal water, Estuaries, Eutrophication, Chlorophyll-a

\section{Introduction}

Tropical estuaries are highly productive due to the essential features of mangroves, which in turn modify the biogeochemistry, nutrients distributions and characteristics of the phytoplankton biomass of the coastal systems (Alongi, 2001; Burford et al., 2008). Oceans are ecosystems that are quite vulnerable to pollution; they are made up of continental shelf and deep sea. The continental shelf and estuaries are the most productive in terms of food supply and are also more susceptible to pollution loads from sediments transported from tributaries (Eruola et al., 2011). Coastal waters serve as interface between terrestrial environments and the open ocean. They are one of the nation's most imperative natural resources, esteemed for their ecological richness as well as for the many human activities they support (Ajibare, 2014). The continental shelf and Estuaries are continuously under the threat of pollution by biological, physical and chemical contaminants that emanate mainly from weathering, hydrological features, precipitation, climate change, erosion, industrial activities, sewage discharge, agricultural land use, and the human exploitation (Liao et al., 2008; Salim and Ashok, 2014). Nutrient concentrations are a common measure in evaluating trophic levels of coastal ecosystems (Balogun and Ajani, 2015). Chronic allochthonous nutrient inputs occur in aquatic ecosystems either from diffuse sources, such as fertilizers or from nonpoint sources (e.g., urban and industrial sewage; Popoola et al., 2015). These have led to a chain of events starting from accelerated growth of primary producers (phytoplankton, macroalgae and aquatic plants), to oxygen depletion, and accumulated massive death of 
aquatic organisms (Cloren, 2001). Nitrogen and phosphorus constituents play a key role in determining the ecological status of aquatic systems, primary productivity and carbon sequestration in coastal waters. They can speed up eutrophication (a reduction of dissolved oxygen in water).

Most studies addressing the causes of eutrophication have concentrated on the elements nitrogen and phosphorus, because both nutrients are majorly discharged by human activities. Silicate, however, also plays a crucial role in algal growth and species compositions, for example, the growth rates of diatoms (silica-shelled phytoplankton) are determined by the supply of silicate (Ittekkot et al., 2000). In the estimation of primary productivity, the Chlorophyll- $a$ indicator is an acceptable and reliable method in estimating micro-algal or phytoplankton production levels in aquatic ecosystems (Onyema, 2013). Increase in the phytoplankton biomass can be measured as an increase in the chlorophyll-a concentration. Therefore, chlorophyll-a is a useful expression of phytoplankton biomass and is arguably the single most responsive indicator of nitrogen and phosphorus enrichment in the marine system (Harding, 1994; Balogun and Ajani, 2015).

The Ilaje Estuary (Fig.1) is a transgressive mud sector in the Southwest Nigeria, and are known for sea foods (e.g., fish, crabs, and periwinkles; Ololade et al., 2008). Pollution therein is liable to have national, global and ecological health effects, because they are one of the typical estuaries in Nigeria that empty into the Atlantic Ocean. (Adebowale et al., 2008; Ajibare, 2014).

The aim of this research is to: (i) evaluate the nutrient (nitrate, nitrite, phosphate and silicate) status in Ondo coastal waters in response to the stress caused by anthropogenic inputs from land use changes, agriculture, and industries. (ii) Determine eutrophication status of the study area using chlorophyll-a scaling proposed by Karydis (1999) and modified by Pavlidou et al., (2005) as an indicator.

\section{MATERIALS \& METHODS}

\subsection{Study Area}

This study was conducted on the coastal region of Ondo State (Lat. 50.50 'N -60.09 'N and Long. 40.45 'E - 50.05 'E). The total area covered by the study was about $500 \mathrm{~km}^{2}$ with emerging communities dispersed within the coast and an increasing population size of $2.2 \%$ annually (Adebowale et al., 2008). The tides in the study area are semi-diurnal and meso-tidal, with a range of $1 \mathrm{~m}$ to $3 \mathrm{~m}$ from the West of Benin River Estuary to the Calabar with range of spring tide, varying from $1 \mathrm{~m}$ in the West of the Benin River to the Calabar Estuary (Sexton and Murday, 1994). 


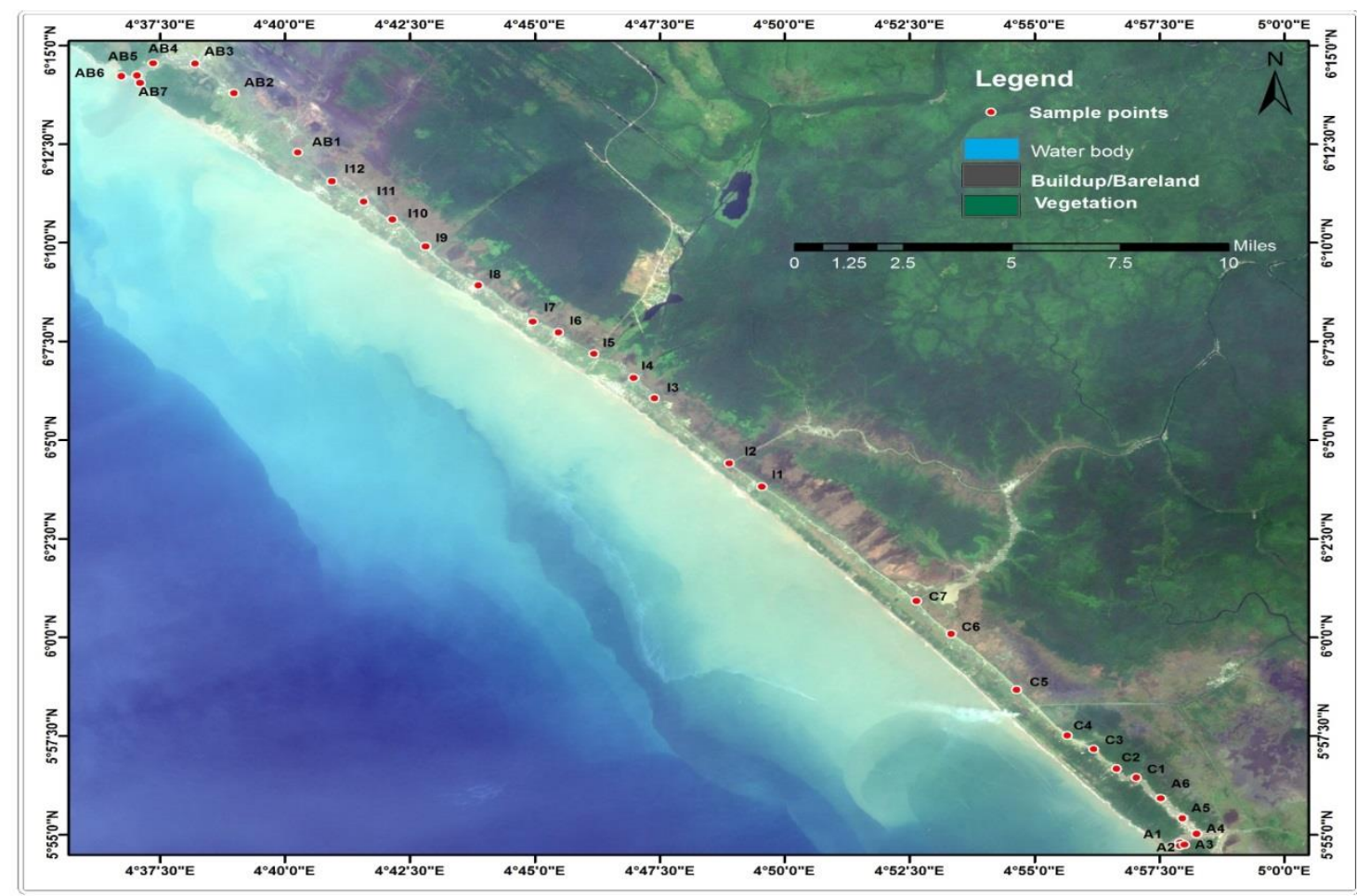

Figure 1: Map of the study area, modified after Nubi et al (submitted).

Trading, fishing and farming are the primary occupation of the coastal dwellers, and the area is known for seafood production of diverse species of fish, crabs, and periwinkles. (Olatunji-Ojo et al., 2019). The fieldwork was conducted in the study area during the rainy period (wet season), in August 2019. Water samples were collected from 32 sampling stations (1-32; Fig.1). The sampling stations consist of two Estuaries Awoye and Abereke which eventually empties into the Atlantic Ocean. Additionally, sampling was conducted at twelve stations (I1-I12) along the communities that settle towards the rivers where there are reported cases of humaninduced activities (Nkwoji et al., 2016). Seven stations (C1-C7), with reduced human induced anthropogenic effluence were selected as control stations.

\subsection{Sampling and Preservation}

Water samples were collected with a plastic 2-litres van Dorn sampler into acid-cleaned polyethylene bottles and per-chloric acid was used to fix the nutrient immediately. The water samples were then filtered through membrane filters of 0.45 micrometer pore size at the time of sampling and then preserved in accordance with standard method (APHA, 1995). Nitrite and nitrate were analyzed using the standard pink azo-dye methods. Phosphate and silicate were determined using the molybdenum-blue methods. In all cases the dissolved inorganic nutrient analyses followed the methods of Parsons et al., (1984). The Phytoplankton pigments (Chlorophyll-a) samples were obtained by filtering the water sampled for each set of samples collected from the creek within 24hrs through Whatman $\mathrm{GF} / \mathrm{C}$ glass fibre filters (approximately $1.2 \mu \mathrm{m}$ pore size). Filters and water samples were stored frozen $\left(-20^{\circ} \mathrm{C}\right)$ until analysis. Filters were transferred to tubes containing 90\% aqueous acetone solution, ground with a Teflon pestle, and the Chl- $a$ extracted in the dark during 24 hours. Extracts were then centrifuged at $3000 \mathrm{~g}$ for 15 minutes and analyzed spectrophotometrically according to the method of Parsons et al., (1984). The pigment concentration was calculated as follows: 
Where:

$\mathrm{V}_{\text {extract }}=$ volume of extract $(\mathrm{mL})$

$\mathrm{V}_{\text {filtered }}=$ volume of sample filtered $(\mathrm{L})$

$\mathrm{L}=$ light path length or width of cuvette, $\mathrm{cm}$

$664 \mathrm{~b}=$ corrected absorbance of extract before acidification

$665 \mathrm{a}=$ corrected absorbance of extract after acidification

The value 26.7 is the absorbance correction factor $(A \times K)$

$\mathrm{A}=$ absorbance coefficient for chlorophyll a at $664 \mathrm{~nm}=11.0$

$\mathrm{K}=$ ratio expressing correction for acidification $=2.43$

Temperature, salinity, dissolved oxygen and $\mathrm{pH}$ were determined in-situ across the 32 stations with the use of Horiba U-52 multiwater parameters to complement the nutrient and chlorophyll-a measurements.

\subsection{Data Analysis}

Data obtained from physical and chemical measurements were statistically analyzed for variance using the Statistical Package for Social Sciences (SPSS), Version 20.0 and was tested at a level $(\mathrm{P}<0.05)$ for significance. The mean values were compared with the water quality criteria of the World Health Organization (WHO, 2008).

\section{Results and discussions}

\subsection{Nutrient}

Nitrate is the final oxidation product of other nitrogen compounds (nitrification) in toxic seawater having a high redox potential. The nitrate form is generally considered the most stable and predominant dissolved inorganic nitrogen in oxygenated sea water (Al-Akhaly et al., 2020). Nitrate concentrations in both (Awoye and Abereke) estuaries follow similar trends, with a range of 1.85-5.16 mg/L and 3.20-6.98 mg/L respectively (Fig.2a-2b). The nitrate concentration decreases with distance from the Awoye estuary (e.g., from station A2-A6, mean value $3.28 \pm 1.45 \mathrm{mg} / \mathrm{L}$ ) in contrast to the Abereke estuary (mean concentration $4.86 \pm 1.55 \mathrm{mg} / \mathrm{L}$ ). The mean nitrate concentrations of the impacted and the control stations are $3.54 \pm 1.77 \mathrm{mg} / \mathrm{L}$ and $4.27 \pm 1.89 \mathrm{mg} / \mathrm{L}$ respectively (Fig.2c, Table 1 ). The control stations showed a decreasing concentration 
(a) Nitrate concentrations in Awoye estuary and the

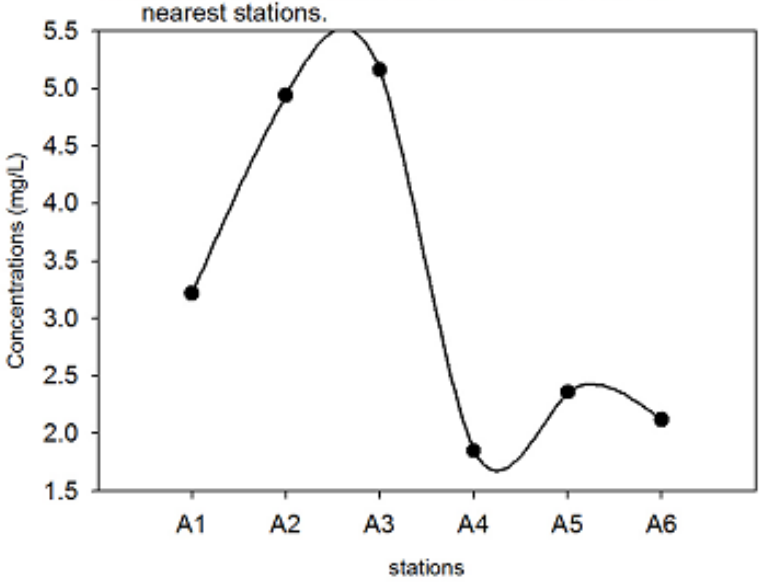

(c) Nitrate concentrations in impacted stations

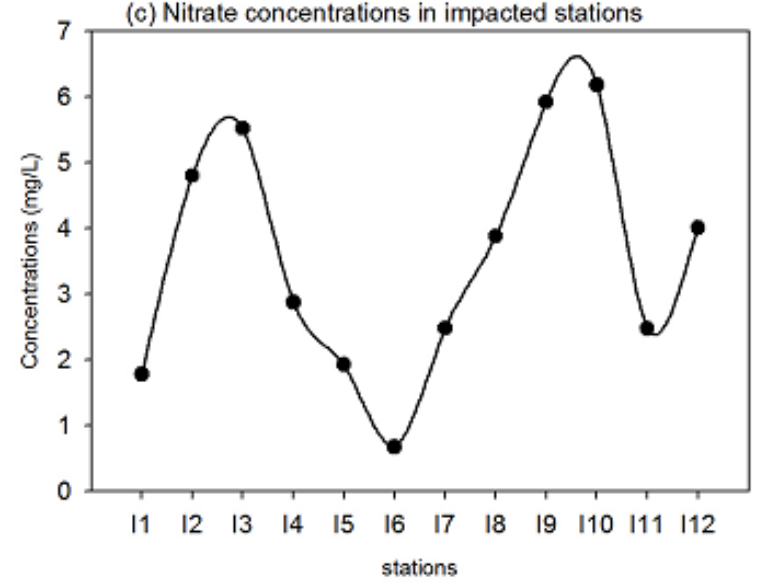

(b) Nitrate concentrations in Abereke estuary and the

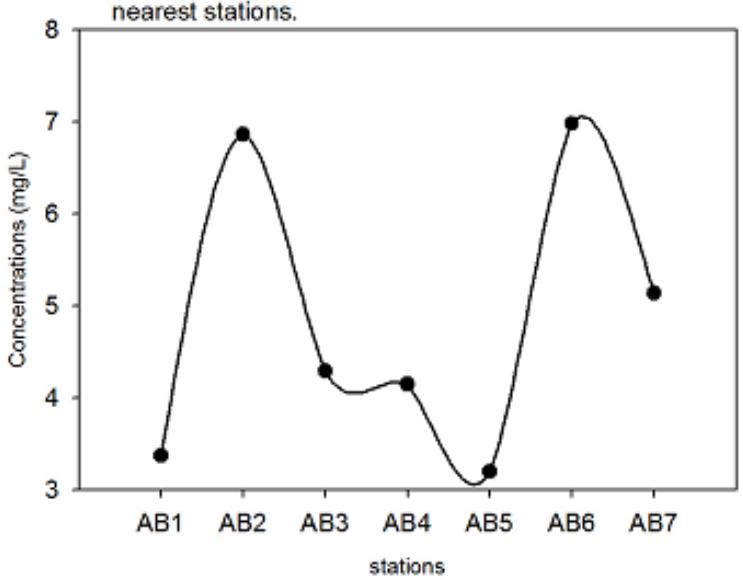

(d) Nitrate concentrations in control stations.

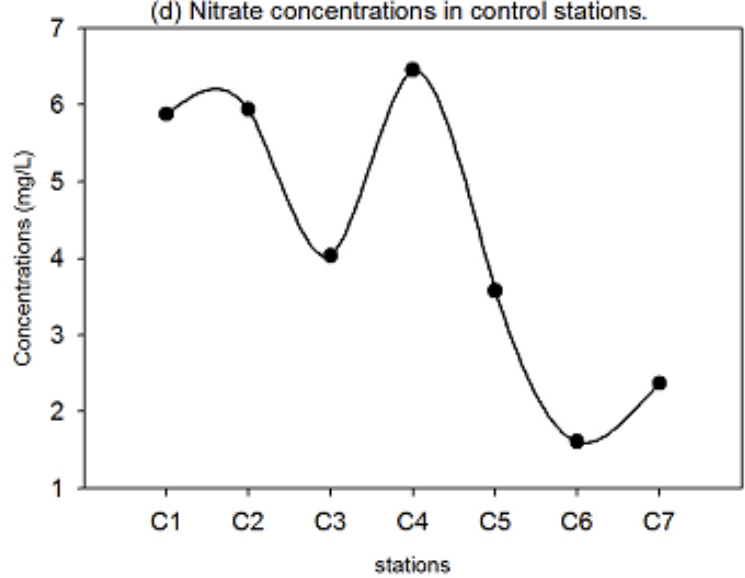

Figure 2. Nitrate concentrations in surface water along the study area.

Table 1. Concentrations (mg/L) of nitrates, nitrite, phosphate, silicate and chlorophyll-a and nitrate/phosphate ratio of the study area

\begin{tabular}{|l|c|c|c|c|l|}
\hline $\begin{array}{l}\text { Sample } \\
\text { No. }\end{array}$ & $\begin{array}{c}\text { Nitrate } \\
(\mathbf{m g} / \mathbf{L})\end{array}$ & $\begin{array}{c}\text { Nitrite } \\
(\mathbf{m g} / \mathbf{L})\end{array}$ & $\begin{array}{c}\text { Phosphate } \\
(\mathbf{m g} / \mathbf{L})\end{array}$ & $\begin{array}{c}\text { Silicate } \\
(\mathbf{m g} / \mathbf{L})\end{array}$ & $\begin{array}{l}\text { Chloropyll-a } \\
(\mathbf{m g} / \mathbf{L})\end{array}$ \\
\hline A1 & 3.22 & 0.08 & 12.45 & 3.12 & 12.83 \\
\hline A2 & 4.94 & 0.02 & 6.28 & 3.33 & 14.97 \\
\hline A3 & 5.16 & 0.06 & 8.43 & 4.26 & 17.11 \\
\hline A4 & 1.85 & 0.02 & 10.24 & 5.86 & 4.28 \\
\hline A5 & 2.36 & 0.01 & 9.3 & 6.74 & 9.98 \\
\hline A6 & 2.12 & 0.03 & 5.39 & 4.69 & 8.55 \\
\hline Mean & $\mathbf{3 . 2 8}$ & $\mathbf{0 . 0 4}$ & $\mathbf{8 . 6 8}$ & $\mathbf{4 . 6 7}$ & $\mathbf{1 1 . 2 9}$ \\
\hline SD & $\mathbf{1 . 4 9}$ & $\mathbf{0 . 0 3}$ & $\mathbf{2 . 6}$ & $\mathbf{1 . 4 2}$ & $\mathbf{4 . 6 5}$ \\
\hline C1 & 5.88 & 0.02 & 4.22 & 8.93 & 18.18 \\
\hline C2 & 5.94 & 0.16 & 5.74 & 5.44 & 19.96 \\
\hline C3 & 4.03 & 0.09 & 2.46 & 5.07 & 14.97 \\
\hline C4 & 6.46 & 0.02 & 4.71 & 4.34 & 19.96 \\
\hline C5 & 3.58 & 0.03 & 8.37 & 7.21 & 13.9 \\
\hline C6 & 1.61 & 0.04 & 7.29 & 7.82 & 5.35 \\
\hline C7 & 2.37 & 0.01 & 8.98 & 6.86 & 8.55 \\
\hline
\end{tabular}




\begin{tabular}{|l|c|c|c|c|l|} 
Mean & $\mathbf{4 . 2 7}$ & $\mathbf{0 . 0 5}$ & $\mathbf{5 . 9 7}$ & $\mathbf{6 . 5 2}$ & $\mathbf{1 4 . 4 1}$ \\
\hline SD & $\mathbf{1 . 8 9}$ & $\mathbf{0 . 0 5}$ & $\mathbf{2 . 3 7}$ & $\mathbf{1 . 6 4}$ & $\mathbf{5 . 6 7}$ \\
\hline I1 & 1.78 & 0.11 & 5.26 & 5.49 & 9.98 \\
\hline I2 & 4.8 & 0.09 & 4.12 & 4.47 & 15.68 \\
\hline I3 & 5.52 & 0.03 & 3.85 & 7.86 & 17.11 \\
\hline I4 & 2.87 & 0.04 & 10.64 & 6.53 & 11.76 \\
\hline I5 & 1.93 & 0.02 & 5.04 & 4.95 & 5.7 \\
\hline I6 & 0.67 & 0.07 & 6.38 & 5.57 & 4.28 \\
\hline I7 & 2.48 & 0.58 & 2.76 & 3.29 & 14.97 \\
\hline I8 & 3.88 & 0.12 & 11.72 & 6.95 & 16.04 \\
\hline I9 & 5.92 & 0.05 & 12.88 & 9.36 & 19.94 \\
\hline I10 & 6.18 & 0.02 & 12.58 & 4.24 & 19.25 \\
\hline I11 & 2.47 & 0.13 & 11.29 & 7.28 & 12.83 \\
\hline 112 & 4.01 & 0.27 & 10.02 & 5.67 & 19.25 \\
\hline Mean & $\mathbf{3 . 5 4}$ & $\mathbf{0 . 1 3}$ & $\mathbf{8 . 0 5}$ & $\mathbf{5 . 9 7}$ & $\mathbf{1 3 . 9}$ \\
\hline SD & $\mathbf{1 . 7 9}$ & $\mathbf{0 . 1 6}$ & $\mathbf{3 . 8}$ & $\mathbf{1 . 7 1}$ & $\mathbf{5 . 1 7}$ \\
\hline AB1 & 3.37 & 0.15 & 14.84 & 2.77 & 17.11 \\
\hline AB2 & 6.86 & 0.08 & 15.61 & 4.28 & 21.38 \\
\hline AB3 & 4.29 & 0.03 & 14.82 & 5.46 & 17.82 \\
\hline AB4 & 4.15 & 0.02 & 11.59 & 3.11 & 19.25 \\
\hline AB5 & 3.2 & 0.09 & 12.26 & 4.82 & 17.11 \\
\hline AB6 & 6.98 & 0.04 & 16.73 & 4.83 & 21.38 \\
\hline AB7 & 5.14 & 0.02 & 17.48 & 5.8 & 18.53 \\
\hline Mean & $\mathbf{4 . 8 6}$ & $\mathbf{0 . 0 6}$ & $\mathbf{1 4 . 7 6}$ & $\mathbf{4 . 4 4}$ & $\mathbf{1 8 . 9 4}$ \\
\hline SD & $\mathbf{1 . 5 5}$ & $\mathbf{0 . 0 5}$ & $\mathbf{2 . 1 7}$ & $\mathbf{1 . 1 4}$ & $\mathbf{1 . 8 3}$ \\
\hline & & & & & \\
\hline
\end{tabular}

from station C4 - C7 (Fig. 2d). The nitrate values in the study area were high compared to the reported values (1.24 $\mu \mathrm{g} / \mathrm{L}$ and $1.34 \pm$ $0.07 \mathrm{mg} / \mathrm{L}$ ) from the Ondo coastal water (Adebowale et al., 2008 and Bolarinwa et al., 2016 respectively). High nitrate levels in the study area could be caused by influx of nitrogen rich flood water arising from the use of nitrogen containing fertilizers, domestic sewage, municipals discharge, animal manure used on cropland, and naturally from atmospheric deposition and the oxidation of ammonia. These influxes bring about large amount of contaminated water into the impacted areas and create the formation of algal blooms in typical coastal environments (Sahoo et al., 2016). Accumulation of nutrients from different anthropogenic sources, or enhanced primary productivity could be responsible for highest nitrate concentrations $(6.98 \mathrm{mg} / \mathrm{L}$ ) recorded at Abereke Estuary (Table 1). Nitrate concentrations in the study area were within the maximum limit quoted by WHO (2008) $(50 \mathrm{mg} / \mathrm{L})$, and contributed approximately $21 \%$ of the total analyzed nutrient in the study area (Fig.3). Nitrate showed a significant positive correlation ( $<<0.01, r$ $=+0.886)$ with chlorophyll a 


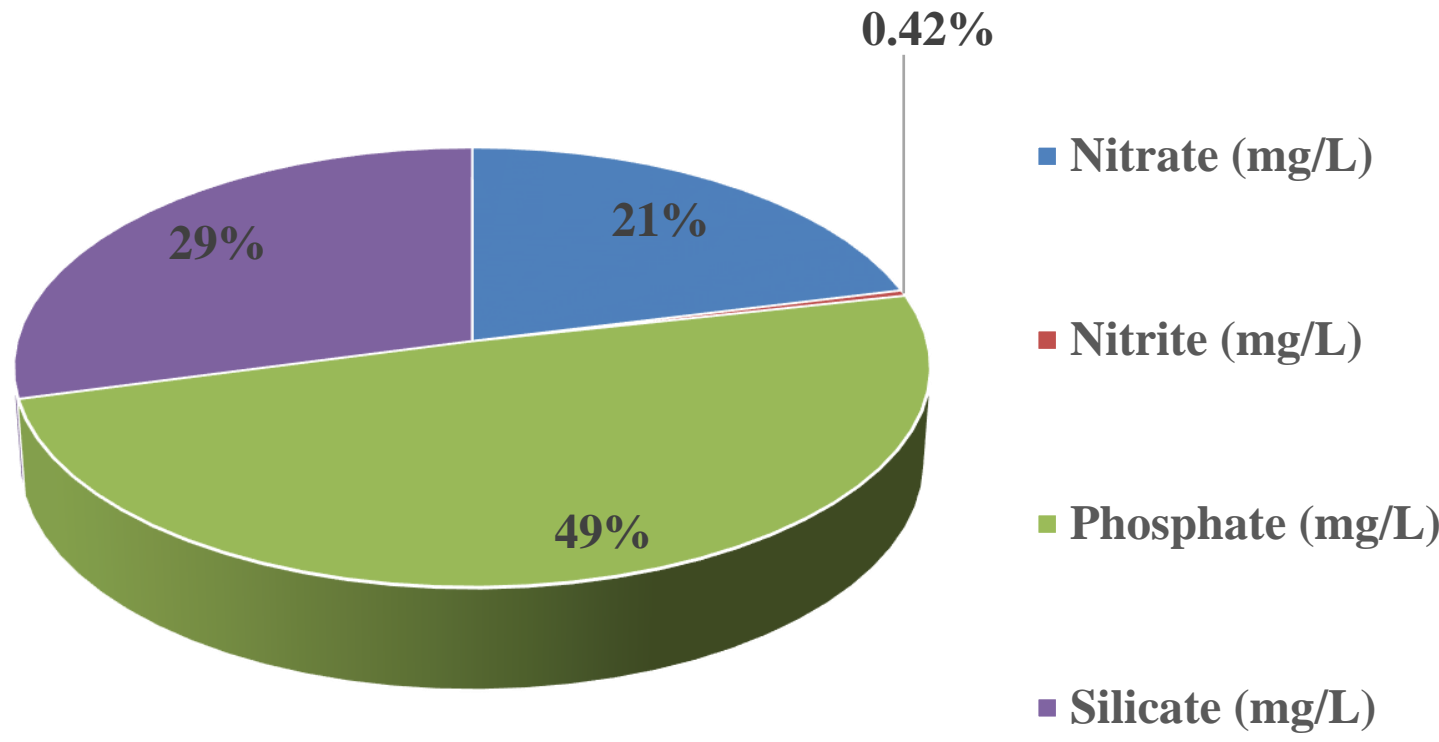

Figure 3: Percentage distributions of Nutrients in the study area

(Table 2), with significant difference across the stations. This study differ from the work of Pérez-Ruzafa et al., (2019) who reported that nitrate, phosphate and silicate showed a significant positive correlation with chlorophyll-a in Mar Menor coastal Lagoon, Spain. Similar studies in the North America coastal systems reported nitrogen as the limiting nutrients of algal populations (Elser et al., 1990 and Downing, 1997).

Nitrite occurs in an intermediate oxidation state between ammonia and nitrate; it can appear as a transient species by the oxidation of ammonia or by the reduction of nitrate (James and Mary, 2015). The nitrite concentrations of Awoye and Abereke Estuaries showed similar trends (Fig. 4a-b), and ranged between $0.01-0.08 \mathrm{mg} / \mathrm{L}$ and $0.02-008 \mathrm{mg} / \mathrm{L}$ with mean value of $0.04 \pm 0.03 \mathrm{mg} / \mathrm{L}$ and $0.06 \pm$ $0.05 \mathrm{mg} / \mathrm{L}$ respectively (Table 1$)$. The highest nitrite concentration $(0.27 \mathrm{mg} / \mathrm{L}$ ) was recorded at station I12 (Table 1) and suggest high anthropogenic sourced effluent at the impacted stations. The maximum permissible limit of nitrite for Tilapia production is $0.06 \mathrm{mg} / \mathrm{L}$ 
(a) Nitrite concentrations in Awoye estuary and the
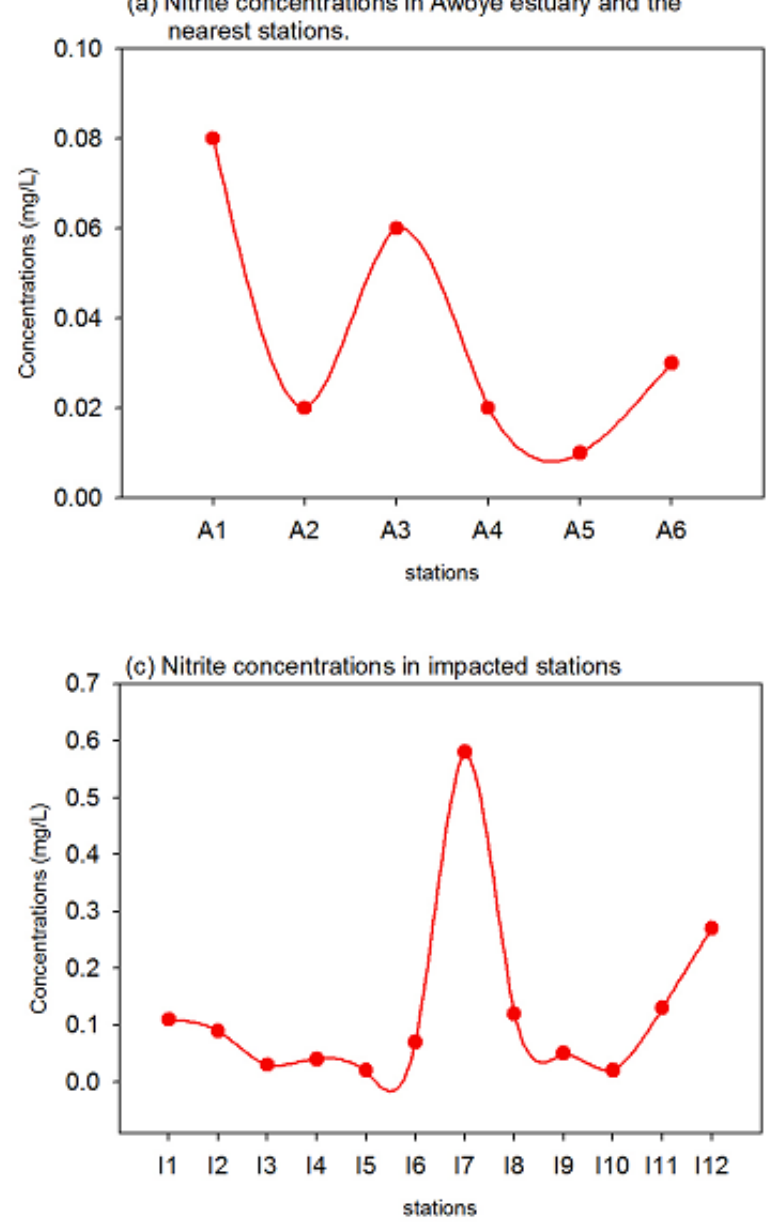

(b) Nitrate concentrations in Abereke estuary and the

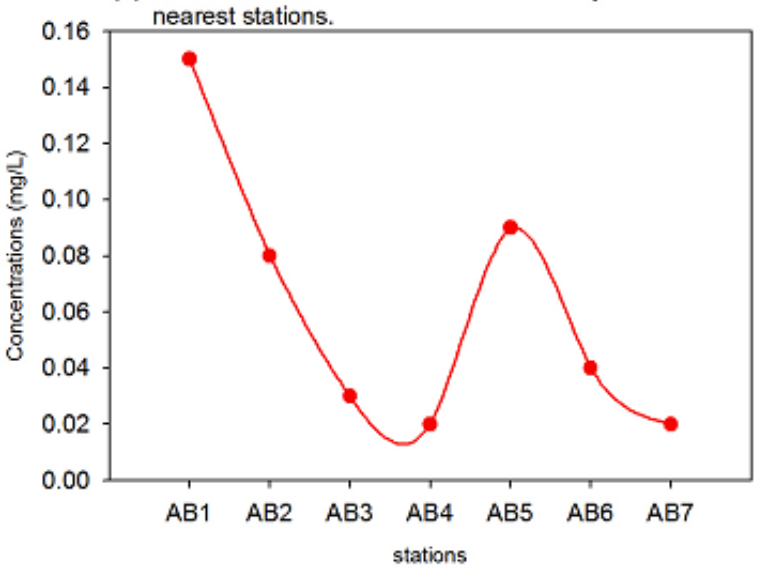

(d) Nitrite concentrations in control stations.

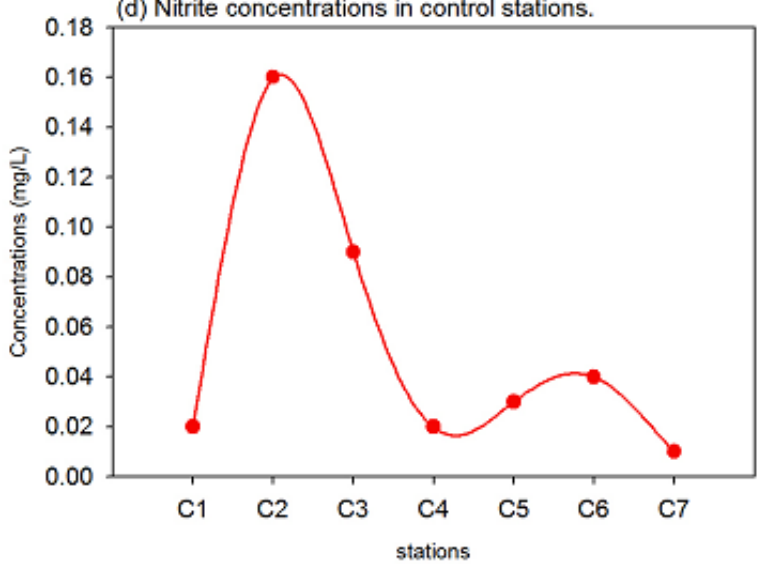

Figure 4: Nitrite concentrations in surface water along the study area.

(Rachman and Adi 2005; El Zokm et al., 2018). The results obtained from our study area suggest that Tilapia fishes will thrive at the Awoye (A1 - A6) and Abereke (AB1 - AB6) Estuaries and the control stations (C1 - C6), with mean nitrite values of $0.04 \pm 0.01$ $\mathrm{mg} / \mathrm{L} ; 0.06 \pm 0.05 \mathrm{mg} / \mathrm{L}$ and $0.05 \pm 0.05 \mathrm{mg} / \mathrm{L}$ respectively. However, the mean nitrate concentration of $0.13 \mathrm{mg} / \mathrm{L}$ at the impacted stations (I1 - I12) suggest an unfavorable environments for the Tilapia fishes' growth. The non-fishing activities in the impacted stations further support these assumptions. Generally, the values of nitrite recorded in the three (Estuaries, control and impacted) study stations were within the maximum limit of $3.0 \mathrm{mg} / \mathrm{L}$ stipulated by WHO (2008). Nitrite contributed the least percentage $(<1 \%)$ to the overall nutrient analyzed in this study (Fig.3). In comparison to other studies, the nitrite concentrations in our study is similar to work of Tadesse et al., (2018) who recorded a range of 0.02 to $0.58 \mathrm{mg} / \mathrm{L}$ at Rebu river in Oromia region, Ethiopia, East Africa.

Phosphorus plays a major role in biological metabolism. It is an essential nutrient element in photosynthesis and other metabolic processes in plants (El Zokm et al., 2018). Higher phosphate concentrations were recorded at Abereke and Awoye Estuaries with a mean value of $14.76 \pm 2.17 \mathrm{mg} / \mathrm{L}$ and $8.68 \pm 2.60 \mathrm{mg} / \mathrm{L}$ respectively (Fig.5, Table 1). The phosphate concentrations in our study area were higher than nitrate values. The phosphate concentrations showed similar trends with the chloropyll-a concentrations at the Abereke and Awoye Estuaries with mean values of $18.94 \pm 1.83 \mathrm{mg} / \mathrm{L}$ and $11.29 \pm 4.65 \mathrm{mg} / \mathrm{L}$ respectively (Table 1). These similar trends suggest the occurrence of heterogeneous phytoplankton biomass and productivity at these estuaries. High phosphates 
concentrations at these estuaries may promote the production of microbes and phytoplankton. Other human induced anthropogenic factors such as chemical

(a) Phosphate concentrations in Awoye estuary and the

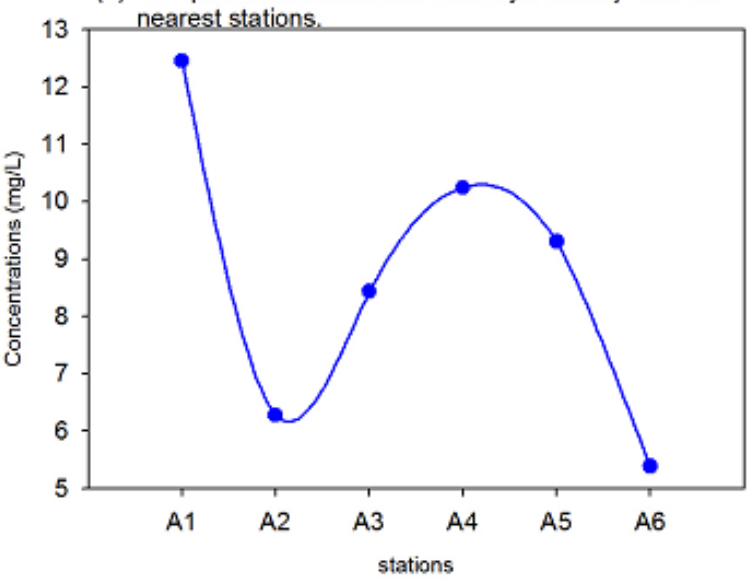

(c) Phosphate concentrations in impacted stations

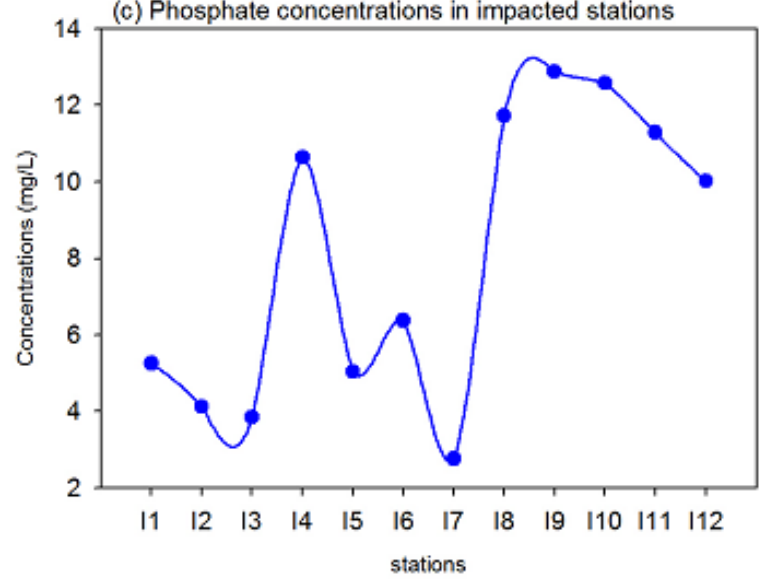

(b) Phosphate concentrations in Abereke estuary and the nearest stations.

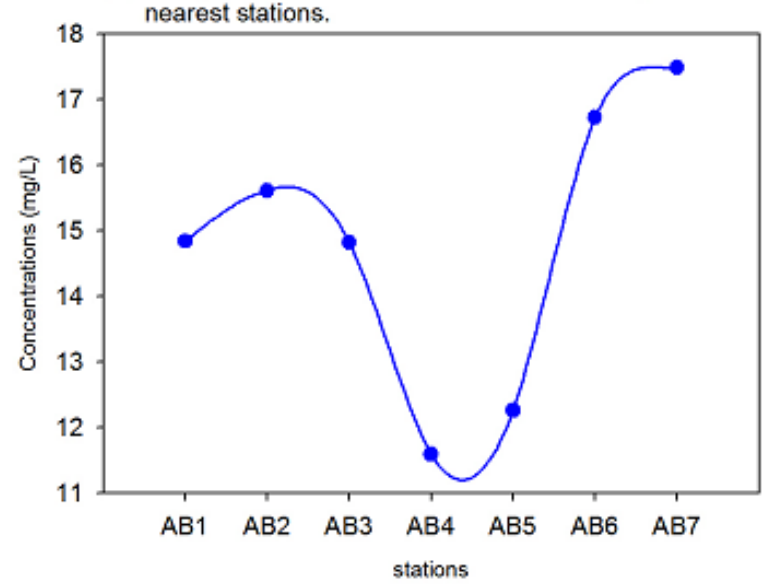

(d) Phosphate concentrations in control stations.

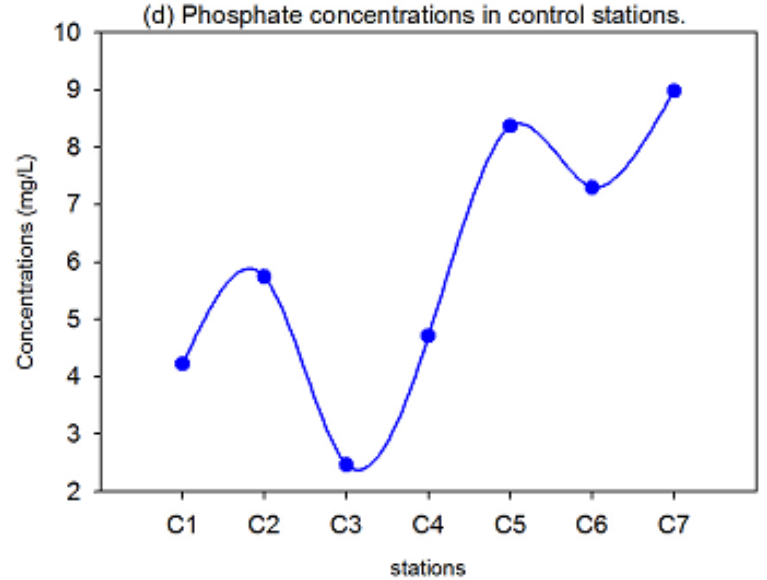

Figure 5. Phosphate concentrations in surface water along the study area.

fertilizer, run-off that are composed of dissolved and suspended phosphate, human or animal waste effluents and effluents from detergents and laundries can trigger the high mean phosphate concentration of the impacted stations and the control stations (Fig 5cd). Additionally, these reported high phosphate concentration can over-fertilize the aquatic plants in the coastal waters and stepped up eutrophication in the Ilaje coastal waters. The Phosphate values in this study were above the permissible limit of $5 \mathrm{mg} / \mathrm{L}$ quoted by WHO (2008) across the sample stations except at C1, C3, C4, I2, I3 and I7 (Fig.5). These results corroborate the work of Ladipo et al., (2012) who reported a mean phosphate concentrations of $9.75 \pm 3.24 \mathrm{mg} / \mathrm{L}$ in the Lagos coastal water, south western Nigeria. The statistical analysis at $95 \%$ confidence level also showed significance differences among the sample stations. Phosphate contributed $49 \%$ percentage to the overall nutrient analyzed in the study area (Fig.3).

The presence of silicate in aquatic environment is very important for growth of diatoms, because diatom contain considerable amounts of silica in the frustule. Low silicate concentrations could influence the course of the spring succession of plankton diatom species in arctic or temperate coastal waters (Alkan, 2013). The silicate concentrations was higher than that of nitrate and nitrite and this could 
be due to heavy influx of freshwater derived from land drainage carrying silicate leached out from rocks and also from bottom sediments exchanging with overlying water due to the turbulent nature of the coastal water (Rajasegar, 2003; James and Mary, 2015).

(a) Silicate concentrations in Awoye estuary and the

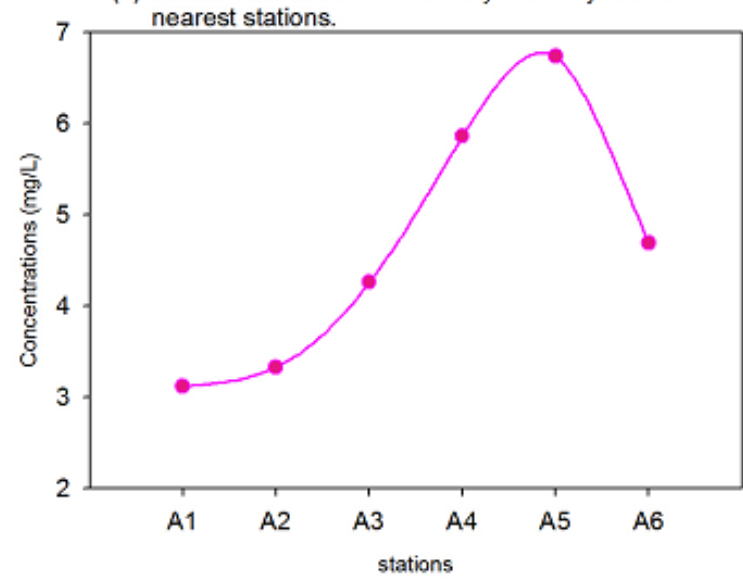

(c) Silicate concentrations in impacted stations

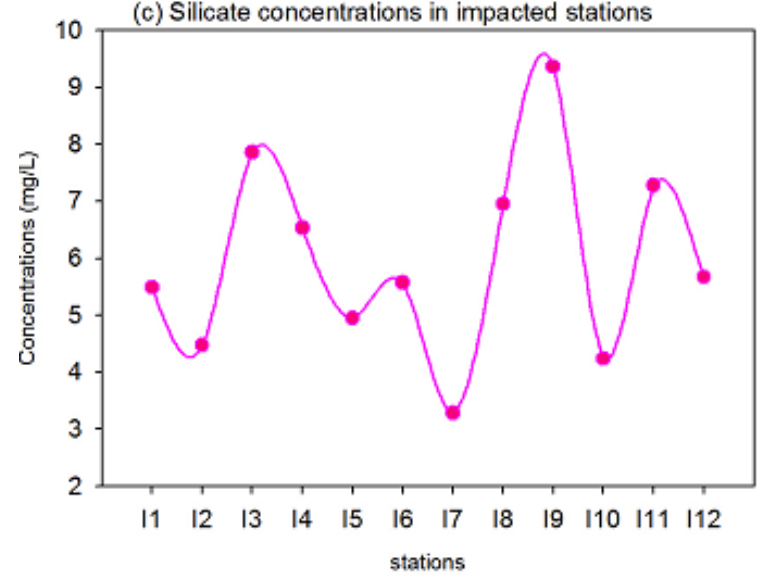

(b) Silicate concentrations in Abereke estuary and the

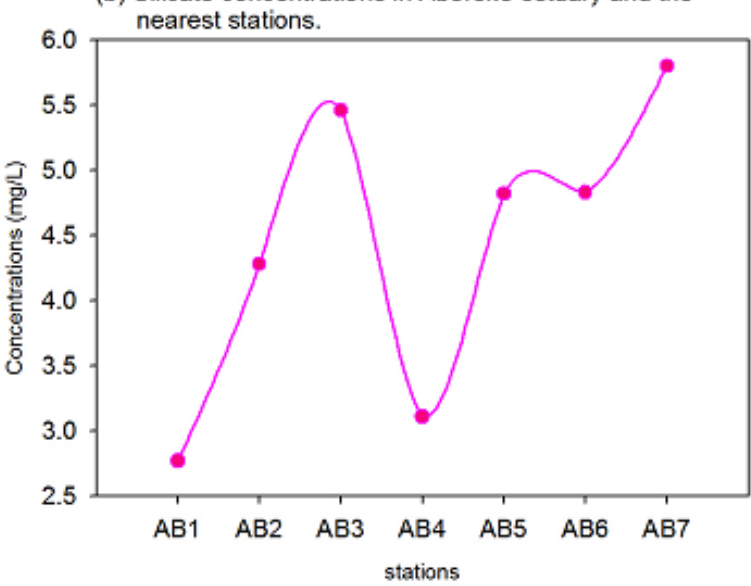

(d) Silicate concentrations in control stations

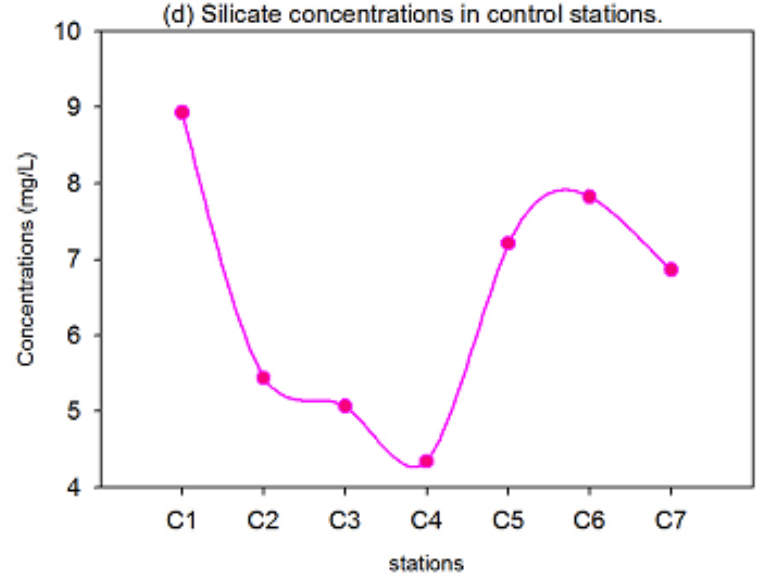

Figure 6. Silicate concentrations in surface water along the study area

It can also be sourced from decaying of existing silicate shells from coastal ecosystems. The highest silicate concentration (9.36 $\mathrm{mg} / \mathrm{L}$ ) was recorded at the impacted station (I9, Fig.6), which support the influence of anthropogenic effluent from discharged run-off at the impacted station, compared to the Abereke and Awoye estuaries. The silicate in the study area was higher when compared to value $(29.72 \pm 8.39 \mu \mathrm{g} / \mathrm{L})$ recorded in the Gulf of Aden and Arabian Sea Coast, Yemen (Al-Akhaly et al., 2020). However, our reported values were lower when compared to the reported values of Amaranadha et al., (2015) and Bolarinwa et al., (2016) who recorded mean concentrations of $28.29 \mathrm{mg} / \mathrm{L}$ and $11.80 \mathrm{mg} / \mathrm{L}$ in the Coastal Water of Pulicat Lagoon (India) and Ondo State, Nigeria respectively (Table 3$)$.

\section{$3.2 \quad$ Chlorophyll-a}

Phytoplankton has been used as an indicator of change in nutrient loads and also serves as a major element for assessing eutrophication in marine systems. Indeed, its assessment has been required by different legislations (Borja et al., 2012; Garmendia et al., 2013; Alexandra et al., 2015). Chlorophyll-a scaling can be a promising tool if applied at spatial structures and therefore, 
heterogeneous water masses can be identified regarding their trophic state (Michelakaki and Kitsiou, 2005; Karydis., 2009). Alexandra et al., (2005) modified chlorophyll-a concentrations scale proposed by Karydis (1999) to comply with the five levels of ecological status implied by the Water Framework Directive (WFD). A new eutrophication scale based on chlorophyll a concentrations was therefore proposed: $\langle 0.1 \mu \mathrm{g} / \mathrm{L}$ high, $0.1-0.4 \mu \mathrm{g} / \mathrm{L}$ good, $0.4-0.6 \mu \mathrm{g} / \mathrm{L}$, moderate, $0.6-2.21 \mu \mathrm{g} / \mathrm{L}$ poor and $>$ $2.21 \mu \mathrm{g} / \mathrm{L}$ bad. Chlorophyll-a varied between $4.28-14.97 \mu \mathrm{g} / \mathrm{L}$ at the Awoye Estuary; $17.11-21.38 \mu \mathrm{g} / \mathrm{L}$ at the Abereke estuaries. The chloropyll-a concentrations at the impacted stations and control stations ranged from $4.28-19.26 \mu \mathrm{g} / \mathrm{L}$ and $5.38-19.96 \mu \mathrm{g} / \mathrm{L}$ respectively (Fig. 7). The recorded values across stations showed that the study

(a) Chl-a concentrations in Awoye estuary and the

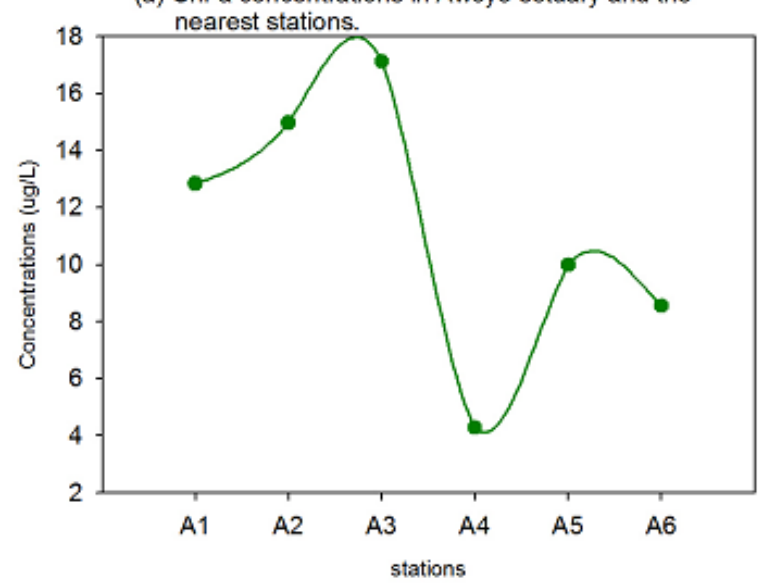

(c) Chl-a concentrations in impacted stations.

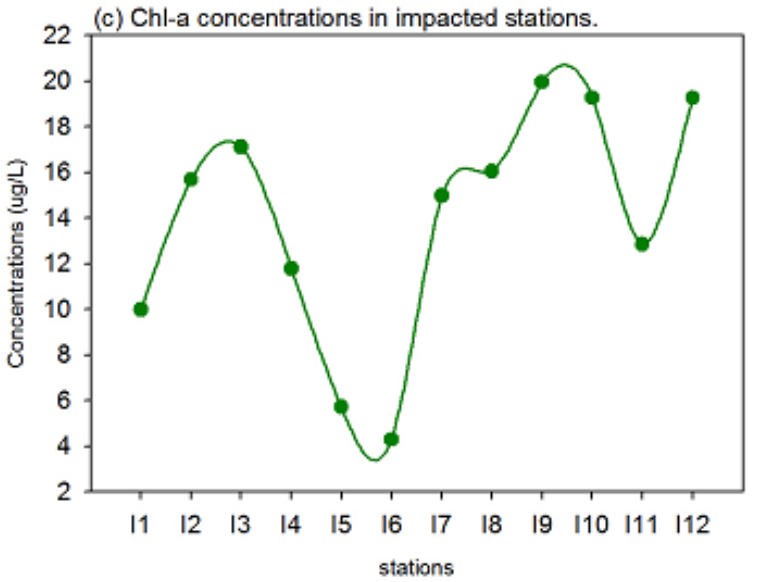

(b) Chl-a concentrations in Abereke estuary and the

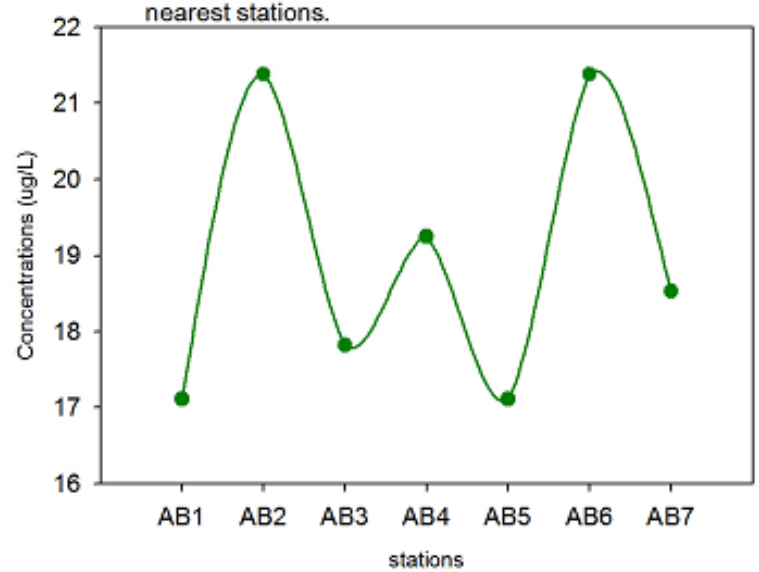

(d) Chl-a concentrations in control stations.

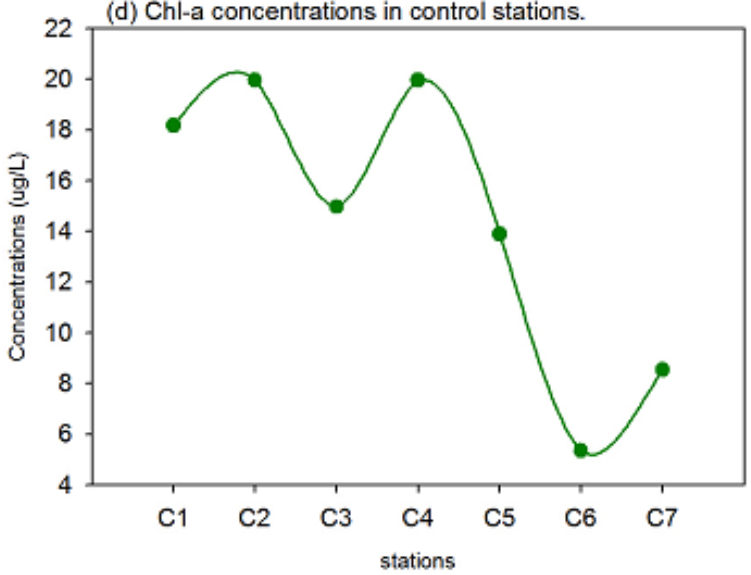

Figure 7. Chlorophyll-a concentrations in surface water along the study area.

area is characterized as bad eutrophication status. Broad range of chlorophyll-a content in the study area could be due to the presence of heterogeneous phytoplankton community during the time of sampling (Titus et al., 2017). The recorded low values at A4 and I6 $(<5 \mu \mathrm{g} / \mathrm{L})$ could be attributed to turbidity of the water, which minimized light penetration and eventually led to low concentration of phytoplankton biomass at the two stations. In comparison to other stations, the mean concentrations of chlorophyll-a of our study area

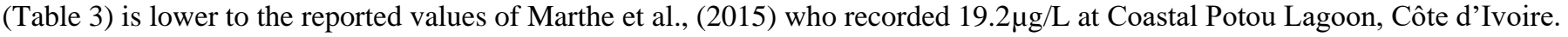


Table 2. Pearson correlation matrix between analyzed and chlorophyll-a (chl-a).

\begin{tabular}{|l|l|l|l|l|l|}
\hline & Nitrate & Nitrite & Phosphate & Silicate & Chl-a \\
\hline Nitrate & 1 & & & & \\
\hline Nitrite & -0.146 & 1 & & & \\
\hline Phosphate & 0.247 & -0.21 & 1 & & \\
\hline Silicate & -0.039 & -0.264 & -0.079 & 1 & \\
\hline Chl-a & $.886^{* *}$ & 0.131 & 0.348 & -0.154 & 1 \\
\hline
\end{tabular}

** Correlation is significant at the 0.01 level (2-tailed).

Table 3. Comparison of Nutrients concentrations of the study area with other published values

\begin{tabular}{|l|l|l|l|l|l|}
\hline Location (authors) & $\begin{array}{l}\text { Nitrate } \\
(\mathrm{mg} / \mathrm{L})\end{array}$ & $\begin{array}{l}\text { Nitrite } \\
(\mathrm{mg} / \mathrm{L})\end{array}$ & $\begin{array}{l}\text { Phosphate } \\
(\mathrm{mg} / \mathrm{L})\end{array}$ & $\begin{array}{l}\text { Silicate } \\
(\mathrm{mg} / \mathrm{L})\end{array}$ & \begin{tabular}{l} 
Chl-a \\
\hline
\end{tabular}
\end{tabular}




\begin{tabular}{|l|l|l|l|l|l|}
\hline $\begin{array}{l}\text { Coastal Waters of Ondo } \\
\text { State,Nigeria } \\
\text { (Bolarinwa et al., 2016) }\end{array}$ & 1.34 & 0.27 & 3.58 & 11.8 & \\
\hline $\begin{array}{l}\text { Coastal Water of Pulicat Lagoon, } \\
\text { India } \\
\text { (Amaranadha et al., 2015) }\end{array}$ & & & & 28.29 & \\
\hline $\begin{array}{l}\text { Lagos Lagoon Nigeria } \\
\text { (Ladipo et al., 2012) }\end{array}$ & 4.86 & & 9.75 & & $19.2 \mu \mathrm{g} / \mathrm{L}$ \\
\hline $\begin{array}{l}\text { Coastal Potou Lagoon Côte d'Ivoire } \\
\text { (Marthe et al., 2015) }\end{array}$ & $3.04 \mu \mathrm{g} / \mathrm{L}$ & $3.7 \mu \mathrm{g} / \mathrm{L}$ & $62.92 \mu \mathrm{g} / \mathrm{L}$ & & 14.62375 \\
\hline $\begin{array}{l}\text { Ilaje coastal water, Ondo state } \\
\text { Nigeria } \\
\text { (This study) }\end{array}$ & 3.938125 & 0.0796875 & 9.1790625 & 5.5125 & \\
\hline
\end{tabular}

\section{Conclusion}

The aim of this research is to evaluate the nutrient (nitrate, nitrite, phosphate and silicate) status in response to the stress caused by anthropogenic inputs from land use changes, agriculture, and industries, and eutrophication status of the Ilaje coastal waters, and Estuaries, Southwest Nigeria, using chlorophyll-a as an indicator. Thirty-two stations consist of two Estuaries Awoye (A1-A6), Abereke (AB1-AB7), anthropogenic impacted stations (I1-I12) and control stations (C1-C7) were sampled.

Our study reveals that the influx of contaminants coming from domestic and industrial effluents, urban storm, and agricultural runoffs has led to the high nitrite, nitrate and silicate concentrations, together with low dissolved oxygen $(<5 \mathrm{mg} / \mathrm{L})$ and acidic $\mathrm{pH}(<6)$ at majority of the impacted stations.

The high level of nitrate in the study area can be traced to diffuse delivery through farmland fertilizer application from adjacent coastal activities. The modified chlorophyll-a concentrations scale further showed that the study area is characterized as bad eutrophication status (> $2.21 \mu \mathrm{g} / \mathrm{L})$.

Detailed information on seasonal variability of parameters in relation to anthropogenic pressures in the estuaries is not fully resolved in this study. This primarily is the situation as our data is limited to wet months of the year. However, a future study program that considers variability in dry months should robustly complements the present work and project a seasonal dynamic that is representative. 


\section{References}

Adebowale K.O., Agunbiade F.O., Olu-Owolabi B.I. (2008). Impacts of natural and anthropogenic multiple source of pollution on the environmental conditions of Ondo State coastal water, Nigeria. J Env Agric Food Chem; 2798 - 2810.

Ajibare A.O. (2014). Assessment of Physico-Chemical Parameters of Waters in Ilaje Local Government Area of Ondo State, Nigeria. International Journal of Fisheries and Aquatic Studies. 1(5): 84-92

Al-Akhaly I.A., Al-Shwafi N.A. and Al-Kabsh S.A. (2020). Distribution of Nutrient Salts and Chlorophyll-a in Surface Water along the Gulf of Aden and Arabian Sea Coast, Yemen. SQU Journal for Science 25(1): 17-25

Alongi D.M. (2002). Present state and future of the world's mangrove forests. Environmental Conservation 29(3): 331-349

Alkan A., Serdar S., Fidan D., Ufuk A., Zengin B., Muhammed B. (2013). Physico-chemical characteristics and nutrient levels of the eastern black sea rivers. Turkish Journal of Fisheries and Aquatic Sciences 13: 847-859

Amaranadha N., Sundara raja B.C., Balayerikala N., (2015). Physico-Chemical Parameters for Coastal Water of Pulicat Lagoon, South East Coast of India. Indian Journal Of Research, 4(10): 153-155

APHA, 1995. Standard methods for the examination of water and waste water, Washington, DC, American Public Health Association, 19th ed.

Balogun K.J. and Ajani E.K. (2015). Spatial and temporal variations of phytoplankton pigments, Nutrients and Primary productivity in water column of Badagry Creek, Nigeria.American Journal of Research Communication. 3(7): 157-172

Bolarinwa J.B., Fasakin E.A., Fagbenro A.O. (2016). Physicochemical analysis of the coastal waters of Ondo State, Nigeria. International Journal of Research in Agriculture and Forestry, 3(11): 13-20

Borja A., Basset A., Bricker S., Dauvin J., Elliot M., Harrison T., Marques J., Weisberg S., West R., (2012). Classifying ecological quality and integrity of estuaries. In: Wolanski, E., McLusky, D. (Eds.), Treatise on Estuarine and Coastal Science. Academic Press, Waltham, 125-162.

Burford M.A., Alongi D.M., Mckinnon A.D., Trott L.A. (2008). Primary production and nutrients in a tropical macrotidal estuary, DarwinHarbour, Australia. Estuarine, Coastal and Shelf Science 79: 440-448 
Cloren J.E. (2001.) Our evolving conceptual model of the coastal eutrophication problem. Marine Ecology Progress Series 211: 223253.

Downing, J.A. 1997. Marine nitrogen: phosphorus stoichiometry and the global N:P cycle. Biogeochemistry 37: 237-252.

Elser J.J., Marzolf E.R., Goldman C.R. (1990). Phosphorus and nitrogen limitation of phytoplankton growth in the freshwaters of North America: a review and critique of experimental enrichments. Can. J. Fish. Aquat. Sci. 47: 1448-1477

El Zokm Gehan M., Tadros Hermine R.Z., Okbah Mohamed A., Ibrahim Galila H., (2018). Eutrophication assessment using TRIX and Carlson's indices in Lake Mariout Water, Egypt. Egyptian Journal of Aquatic Biology \& Fisheries, 22(5): 321 - 339

Eruola, A. O.,Ufoegbune, G. C.,Ojekunle, Z. O.,Makinde, A. A., Ogunyemi, I. O., (2011). Analytical Investigation of Pollutants in Lagos Coastal Waters, Nigeria.Advances in Analytical Chemistry. 1(1): 8-11

Garmendia M., Borja A., Franco J., Revilla M.J. (2013). Phytoplankton composition indicators for the assessment of eutrophication in marine waters: Present state and challenges within the European directives. Mar. Pollut. Bull. 66: 7-6.

Harding L.W. (1994). Long-term trends in the distribution of phytoplankton in Chesapeake Bay: roles of light, nutrients and stream flow. Marine Ecology-Progress Series 104: 267-267

Ittekkot V., Humborg C., Schäfer P., (2000). Hydrological alterations and marine biogeochemistry: a silicate issue?. BioScience 50(9): 776-782

James B.A.D. and Mary J.K.S. (2015). Study on Hydrographic properties in the coastal waters along South East Coast of India. American Journal of Engineering Research, 4(6): 203-214

Karydis M. (1999) Evaluation report on the eutrophication level in coastal Greek areas. University of the Aegean, Mytilini, February 1999 (in Greek)

Karydis M. (2009). Eutrophication assessment of coastal waters based on indicators: a literature review. Global NEST Journal, 11(4):373-390.

Nkwoji J.A., Yakub A.S., Abiodun A.O., Bello B.O. (2016). Hydrochemistry and community structure of benthic macroinvertebrates in Ilaje coastal waters, Ondo state, Nigeria. Regional Studies in Marine Science 8: 7-13

Ladipo M.K., Ajibola V.O., Oniye S.J. (2012). Application of Multivariate Statistical Methods to Assessment of Water Quality in Selected Locations of Lagos Lagoon, Nigeria, Environmental Research Journal, 6(3): 141 -150.

Liao S., Gau H., Lai W., Chen J., Lee C. (2008). Identifiation of pollution of Tapeng Lagoon from neighbouring rivers using multivariate statistical method.Journal of Environmental Management 88(2): 286-292

Marthe Y.K., Lanciné G.D., Bamory K., Aristide D.G., Ardjouma D. (2015). Seasonal and Spatial Variations in Water Physicochemical Quality of Coastal Potou Lagoon (Côte d'Ivoire, Western Africa). Journal of Water Resource and Protection, (7):741-748 
Michelakaki M., and Kitsiou D. (2005) Estimation of anisotropies in chlorophyll $\alpha$ spatial distributions based on satellite data and variography, Global Nest Journal, 7, 204-211.

Olatunji-Ojo A.M., Olayinka-Olagunju J., Adejuyigbe A (2019). Ecological risk assessment of heavy metals in sediment from oilproducing regions of Ilaje local government area of Ondo state, Nigeria. International Journal of Research and Scientific Innovation 6(6): $263-270$

Onyema I.C. (2013). Primary production and nutrients in an Open Tropical Lagoon. Nature and Science 11(3): 102-106

Parsons T.R., Maita Y., Lalli C. M. (1984). A manual of chemical and biological methods for seawater analysis. Pergamon. Press 173.

Pavlidou A., Simboura N., Rousselaki E., Tsapakis M., Pagou K., Drakopoulou P., Assimakopoulou G., Kontoyiannis H., Panayotidis H. (2015). Methods of eutrophication assessment in the context of the water framework directive: Examples from the Eastern Mediterranean coastal areas. Continental Shelf Research. 108: 156-168.

Pérez-Ruzafa A., Campillo S., Fernández-Palacios J.M., García-Lacunza A., García-Oliva M., Ibañez H., Navarro-Martínez P. C., Pérez-Marcos M., Pérez-Ruzafa I.M., Quispe-Becerra J.I., Sala-Mirete A., Olga S., Marcos C. (2019). Long term dynamics in nutrients, chlorophyll a, and water quality parameters in a coastal lagoon during a process of euthrophication for decades, a sudden break and a relatively rapid recovery. Frontiers in Marine Science, 6(26): 1-23

Popoola S.O, Nubi, O.A., Adekunbi, F.O, Oyatola, O.O, Fabunmi, G.I Nwoko, C.J. (2015). Vertical profiling and contamination risk assessment of some trace metals in Part of the Lagos Lagoon axis. International Journal of Science, Technology and Society 3(4): 186-193.

Rachman B. and Adi S., (2005). Practices for Carp and Tilapia Grow Out in Cages, Sukabumi Research Water Aquaculture Development Center, Department of Fisheries and Marine Affairs, West Java, Indonesia.

Rajasegar M. (2003). Physico-chemical characteristics of the Vellar estuary in relation to shrimp farming. J. Environ. Biol. 24: 95101.

Sahoo M., Mahananda M.R., Seth P. (2016). Physico-Chemical Analysis of Surface and groundwater around Talcher coal field, district Angul, Odisha, India. Journal of Geoscience and Environment Protection, 4: 26-37

Salim A. B., and Ashok K. P., (2014). Surface Water Quality Assessment of Wular Lake, A Ramsar Sitein Kashmir Himalaya, Using Discriminant Analysis and WQI. Journal of Ecosystems. 1-18

Tadesse M., Leku D.T., Girma G. (2018). Assessment of the level of some physicochemical parameters and heavy metals of Rebu river in Oromia region, Ethopia. MOJ Biology and Medicine 3(4): 99-118

Titus L.P., Deepananda Ashoka K.H.M, Cumaranatunga P.R.T., (2017). Physicochemical environment of Malala Lagoon in Southern Sri Lanka. Sri Lanka J. Aquat. Sci., 22(2): 129-139

WHO (2008). Guidelines for Drinking Water Quality: Recommendations. $3^{\text {rd }}$ edition. Geneva: World Health Organization 1:515. 
International Journal of Scientific and Research Publications, Volume 11, Issue 10, October 2021 